\title{
The Interdisciplinary Study of Legal Evolution
}

\author{
Robert C. Clark ${ }^{\dagger}$
}

\section{Thesis}

There is an important kind of legal scholarship that should be done to a much greater extent than it is now. I call this type of scholarship the interdisciplinary study of legal evolution (ISLE). Its object is to understand, to predict, and to influence changes in legal rules and in the institutions that they shape.

At its best, this kind of study should have four important characteristics. First, it should be more scientific in aspiration than are most historians' accounts of legal change: it should seek to identify and to test lawlike generalizations about changes in specific fields of law. Second, it should be more systematic and methodical than are many historians' accounts of legal change: a major effort should be made, in one area after another, to examine interesting legal changes by use of an identifiable set of procedures. Third, it should be more interdisciplinary than are many traditional accounts by lawyers of legal rules: it should use the concepts, data, and empirical studies supplied by the social sciences-principally by economics in many areas, but by other fields as well. Fourth, it should be more institutional and doctrinal than is some of the interesting recent theoretical work by economic analysts on the evolution of the common law: its analysis of systems of legal rules and nonlegal practices should be detailed in its attention to particular institutions and doctrines.

I do not argue that this kind of study of legal change should displace other kinds of legal scholarship, that it should be regarded as the most important kind of scholarly activity for law professors, or that it would best serve some mythical "primary function" of legal scholarship. Nor do I believe that anyone is already doing it as it should be done at its best. My claim is simply that it is desirable that more and better effort be devoted to the interdisciplinary study of legal evolution.

The second part of this paper argues that the scientific aspiration of ISLE is a realistic one. My suggestion is that one can identify

\footnotetext{
$\dagger$ Professor of Law, Harvard University.
} 
many interesting, testable generalizations about significant sets of legal changes, and that often one can formulate and test explanations of these general trends of change. The third part of the paper suggests some semiformal methodological guidelines for use in ISLE. The fourth part discusses the meaning, value, and limits of the interdisciplinary component of ISLE. The fifth part assesses the reasons for detailed focus on specific institutions and doctrines. The sixth and final part offers some reflections on the functions and values of ISLE and of other kinds of legal scholarship.

\section{Feasibility}

The cautious, anti-generalist law professor trained in adversarial techniques and nourished by the Socratic method will be skeptical of my program. He will object that actual changes in legal rules and in the institutions that they shape are nearly always too complicated to permit anyone to draw out of them generalizations that are definite in meaning, empirically disconfirmable by potentially obtainable evidence, yet fairly simple and useful or interesting. Moreover, it will be said, to devise reasonably complete, covering-law explanations ${ }^{1}$ of any such general trends as may occasionally be shown to exist will

1. See W. Dray, Laws and Explanation in History (1957) (coining name "covering law model" for model of scientific explanation as deduction of real-world consequences of general scientific laws); E. Nager, The Structure of Science 29.46 (1961) (the deductive pattern of explanation); Hempel \& Oppenheim, Studies in the Logic of Explanation, 15 Philosophy of Science 135 (1948), reprinted in C. HeMPel, Aspects of Scientific Explanation 245-90 (1965) (key formulation of deductive-nomological model). In more recent times, many aspects of what Patrick Suppe has called the "Received View"-the account of scientific theories by philosophers such as Hempel, Popper, and Carnap that grew out of logical positivism, but survived much longer than that more general movement-have been vigorously criticized-on the basis, for example, of Thomas Kuhn's well known work, The Structure of Scientific Revolutions, published in 1962 . The criticisms produced a period of Weltanschauungen or "world view" analyses of scientific theory, and the perceived faults of these analyses have led other philosophers, such as Dudley Shapere, to pursue more moderate approaches that might be called "historical realism" about theories. See Suppes, The Search for Philosophical Understanding of Scientific Theories, in THE Structure of ScIentific Theories 3-241 (P. Suppe ed. 1977); Suppes, Afterword-1977, in The Structure of Sclentific Theories 617-728 (P. Suppe ed. 1977). Among the complaints about the Hempel and Popper views is that they overemphasize the extent to which deduction, prediction, and testing characterize scientific theorizing, and fail to appreciate the degree of immunity to falsification that many theories have had. See Hilary Putnam's Scientific Explanation, in THE STRUCTURE of Scientific Theories 424-33 (P. Suppe ed. 1977). But see van Fraasen, Putnam on the Corroboration of Theories, in THE STRUcture OF Scientific TheORIEs 434-36 (P. Suppe ed. 1977) (criticizing "pragmatic" views of Putnam).

These intramural disputes do not, I think, affect my basic assumption throughout the paper that legal scholars' lawlike generalizations should be established in methodologically careful ways by reference to empirical evidence, and that doing so is important and valuable (for, inter alia, theory building). 
nearly always be a hopelessly complicated and ad hoc task, producing only weak results of no use for forecasting, retrodicting, or understanding other legal changes. After all, it is pretty clear-isn't it? -that later generations of scholars demolished Langdell's notion that law is a science, and something like a neo-Langdellian rashness lies behind the concept of ISLE.

My answer to these objections is, "Not so." It is impossible to prove the opposing propositions in any one work, of course, so I must content myself with suggesting the feasibility of a program for the study of legal evolution. I shall do this by reviewing some instances of lawlike generalizations about important developments in legal rules and law-shaped institutions. In some cases, I shall sketch what seem to be reasonable explanations of these general trends.

The examples that will be reviewed are taken from my own work, both published and unpublished. This fact causes me some embarrassment, and prompts both a justification and an explanation. The justification is not that no good examples could be taken from the work of other legal scholars (some could ${ }^{2}$ ), but that $I$ am more aware of underlying data with respect to each of my own examples, and therefore feel both reasonably confident of the validity of the generalizations and willing to be called to task for any alleged errors. The explanation is simply that the questions put by the sponsors of this symposium quite naturally led me to reflect at some length on what I have actually been doing in my several years of writing on legal subjects. Interestingly, the objectives and themes I have been repeatedly pursuing seem to be rather different from those that might be suggested by any conventional description that $I$ or others would give of my own scholarship. ${ }^{3}$ Perhaps most academic lawyers who have reflected on their work could make this observation. Having reflected on my work, I still do not know whether academic lawyers usually rationalize the past, finding in it a purpose and direction that is not really there, or whether it usually leads one to uncover agendas

2. See, e.g., R. Adeistein, Instrtutional Function and Evolution in the Criminal Process (1980); Kagan, Cartwright, Friedman, \& Wheeler, The Business of State Supreme Courts, 1870-1970, 30 Stan. L. Rev. 121 (1977); Kagan, Cartwright, Friedman, \& Wheeler, The Evolution of State Supreme Courts, 76 Mich. L. REv. 961 (1978). See also notes 50-52, 54,56 infra.

3. An observer might describe that scholarship as concerned with the corporate and financial world and say that it is characterized by variety and broad scope, by a tendency to classify and synthesize, by references to systematic empirical studies, by use of concepts from economics, financial theory, and other disciplines, and by legislativereform proposals that often involve selective deregulation. But there is also a recurring pattern of resort to stories about how the law has evolved. 
actually implicit in the past; but I am certain that both particular legal scholars and the entire legal culture can follow intellectual patterns without being aware of them ${ }^{4}$ and that it is both possible and useful to discover those patterns.

\section{A. Some Apparently General Patterns of Change}

Before reviewing examples, I shall describe two general patterns of development that many of them seem to exemplify, or of which they are a part. The first pattern has four phases. First, technological, social, or other external changes occur that create new opportunities for legal rules to reduce costs or disutilities of certain kinds. Those costs are often transaction costs, ${ }^{5}$ though other costs and disutilities also arise from particular risks and uncertainties. ${ }^{b}$ Second, a responsive legal invention occurs. A legal principle (or family of legal principles), or an institution defined and shaped by legal principles, is created or used anew; it reduces the costs or disutilities better than identifiable alternatives; ${ }^{7}$ and instances of the principle or institution proliferate. One is inevitably tempted to analogize the process to Darwin's natural-selection view of the origin of species. ${ }^{8}$ Third, the rise of the successful legal principle or institution itself creates new needs and opportunities for cost reduction. Fourth, substantial legal activity occurs-resulting in statutes, regulations, and case law -in an apparent attempt to exploit these opportunities, or at least with that objective result. In this phase, legal activity is apt to involve fairly obvious struggles over the distribution of cost savings.

The two kinds of law-related cost reduction might be called "primary" and "secondary." These terms are relative, of course, and their application will depend on where one starts the analysis. In many applications, however, it will appear that primary cost reduction is brought about by rather basic, simple principles of institutional de-

4. Cf. J. March \& J. Otsen, Ambiguity and Chotce in Organizations 54-68 (2d ed. 1979) (organizational learning theory based in part on notion that people habitually impose order, attribute meaning, and create explanations for ambiguous, past experience).

5. For example, a business firm not possessed of legal personality incurs large legal and administrative expenses when it seeks to record deeds to real property in many countries. Similarly, the creditors of a firm with thousands of owners but no limited liability incur high costs when they try to enforce claims against owners' personal assets.

6. For example, some cost or disutility arises from the illiquidity risk of holding ownership interests that are not freely transferable.

7. Often, the competition seems to be mainly among principles or institutions; at the time, it is not immediately clear whether or how the cost saving to one group of people comes at the expense of another.

8. See C. Darwin, The Origin of Species by Means of Natural Selection (London 1859). 
sign, whereas secondary cost reduction is not achieved without a lengthy, complex efflorescence of doctrinal detail. Legal developments associated with secondary cost reduction are more likely, therefore, to yield to analysis as an essentially "closed system," that is, as a system in which lines of development in legal doctrine can usefully be studied and explained without much appeal to changes in exogenous factors.

I am not asserting that this recurrent pattern of change is the most significant one, that it will be found in connection with legal developments outside the corporate and financial sphere, or even that it will be found in many developments within that sphere. Those issues await further study of legal evolution in particular contexts. Moreover, I am not asserting that the full set of law-related, cost-reducing activities often, or even ever, proceeds to a socially optimal level.

A second, fairly general pattern of change illustrated by the examples below is the close connection between changes in the size of economic units or transactions and the subsequent development of new institutions and rules. In particular. the great increase during the last two hundred years in the size of business firms, in the number of investors or capitalists, and in the amount of wealth in the economy-these developments, of course, are related-is extraordinarily important in understanding the rise of new forms of organizations (first example), new roles and the laws governing them (second example), new legal doctrines (third example), and new kinds of legal proceedings (fourth example). Indeed, in the corporate and financial area, scalar differences seem to be almost as important as they are in physics and biology.

\section{B. Some Examples of Legal Evolution}

The examples offered differ greatly in the scope and specificity of the developments analyzed. The first two presentations are fuller and loosely follow the method of analysis proposed in the next part. The others are more selective and sketchy.

\section{Corporate Law}

The development of corporate law and securities regulation in the United States displays clearly both primary and secondary cost-reducing activities that fit the postulated general pattern. Consider, first, the primary phase and this testable description of the general trend: in the late nineteenth and early twentieth centuries, a legal form of organization, the business corporation, began to appear with 
increasing frequency as the vehicle within which an ever larger volume of business was conducted. The process can be measured and tested in various ways. For example, the percentage of gross business receipts accounted for by businesses in corporate form increased substantially, thus shifting the distribution of receipts away from businesses organized as partnerships, business trusts, and the like. The change can properly be described as involving legal evolution because what occurred was not merely a growth in large-scale business firms, but a growth in one form of organization at the expense of competing forms.

A form of organization is constituted by a particular set of defining legal principles. In the case of the corporate form, the set includes the principles of limited liability, free transferability of shares, strong legal personality, and centralized management. ${ }^{9}$ The business world applied this constellation of principles much more than other constellations. At the same time, the legal world created, refined, and developed the principles of the corporate form. The emergence of the corporation in its modern guise represents a legal invention.

An explanation of this legal invention, and of its competitive success, may be proposed and tested. In the latter part of the nineteenth century, certain conditions came to full force together: because of technological changes, large-scale industries became feasible and efficient for the first time; the general level of wealth increased, but was not extremely lopsided in distribution; and private ownership of capital goods was accepted as a social and legal norm. Under these conditions, a form of organization that could facilitate both the aggregation of large sums of capital from numerous scattered investors and the operation and management of a large scale business was preferentially selected over other forms by the cumulative decisions of rationally self-interested entrepreneurs and investors. The business corporation was just such an efficient form. It can be shown analytically, for example, that each of its defining legal characteristics lowers transaction or information costs of important kinds, or reduces significant risks or uncertainties, better than the corresponding characteristics of the partnership form. ${ }^{10}$ Some lawyers and commentators in the period of the corporation's rapid growth clearly perceived these efficiencies. ${ }^{11}$ Ever since that time, the corporate form has been selected or retained for the larger business enterprises. Moreover, in principle one could test the proposition that, other things being equal, large-scale business

9. See R. Clark, Corporate Law, ch. 1 (1981) (unpublished manuscript) (on file with Yale Law Journal).

10. See id. at 14-49.

11. See, e.g., W.W. Coox, Tue Corporation Problem 1-4 (1891). 
organizations in corporate form were more profitable to their managers and investors than were other forms.

This evolutionary explanation should confront apparently inconsistent facts. For example, one of my colleagues has protested that the major reason for the rapid increase in very large corporate firms in the late nineteenth century was actually the oft-recognized wave of mergers and acquisitions, many of them anticompetitive in intent. ${ }^{12}$ But this phenomenon is consistent with the evolutionary explanation. To what extent businesses grew by acquisition rather than internally, and to what extent acquisitions were anticompetitive, are questions largely irrelevant to the proposition that big firms, however created, were preferentially operated in corporate form. By contrast, it would tend to disconfirm the evolutionary explanation if there were evidence that the foilowing pattern occurred: whenever a number of medium-sized corporate businesses merged, the controlling parties kept the corporate form for the survivor; but whenever a number of medium-sized noncorporate businesses consolidated, the controlling parties kept the noncorporate form indefinitely. That is, the evolutionary explanation would be weakened by evidence that assemblers of huge combines of smaller units experienced no desire or need to shift to the corporate form. Of course, that some first-wave consolidations of smaller companies into long-lasting giants involved no real economies and were based solely on anticompetitive schemes puts into perspective my proposition that technological changes provided an impetus to the creation of large-scale business enterprises. But it would be unpersuasive to go on to assert that the growth in the average size of business firms-as compared, for example, to the average size in colonial times -was not due in any substantial (if undetermined) part to technological changes and real economies of scale. ${ }^{13}$

One virtue of the evolutionary explanation is that it suggests a systematic series of thought experiments for the purpose of analyzing and understanding alternative paths of development. Alternative paths

12. The first of the three or four intense merger waves in the United States occurred between 1887 and 1904 and involved approximately $15 \%$ of all assets and employees engaged in manufacturing at the turn of the century. Markham, Survey of Evidence and Findings on Mergers, in Business Concentration and Price Policy 141, 157 (Universities-National Bureau of Economic Research ed. 1955). Of approximately $\mathbf{3 0 0 0}$ independent-firm disappearances due to merger, $75 \%$ involved at least five firms. $R$. Nelson, Merger Movements in American History, 1895-1956, at 28-29 (1959). Because many of these unions were horizontal consolidations in search of market dominance, George Stigler has called them "mergers for monopoly." Stigler, Monopoly and Oligopoly by Merger, AM. Econ. Rev. (Papers and Proceedings), May 1950, at 23, 23-24.

13. See A. Chander, The Visible Hand 48-51, 75-78, 285-89, 337-39 (1977). 
might actually have been taken in other countries, or they might occur in the future as a result of planned or unplanned changes in the relevant exogenous variables. By elaborating these possibilities, one may check the power and utility of the original explanation.

Suppose, for example, that one of the three environmental conditions favoring growth of the corporate form is changed. A society might have a reasonably wide distribution of wealth and advanced technology, but little private ownership of capital goods. Perhaps this describes the Soviet Union today. In such a society, one would expect the state to raise savings from its citizens and to channel them to business enterprises. There would be little need for the dominant law of the organization of state enterprises, which in a general sense could be called the state's "corporate law," to provide for freely transferable shares whose owners were automatically blessed with limited liability. There would be less need than in our system for strong legal personality in some important respects, such as possession of indefinite lifespan. Because the state that orns a business would be less likely than a series of individual investors to risk destroying a firm's goingconcern value by demanding immediate repayment of its investment in order to meet particular liquidity needs, and would have strong incentives to preserve firms whose going-concern value exceeded their liquidation value, there would be little need for legal rules that restrain an enterprise owner's ability to force a corporate liquidation. In addition, one would expect management in a state-owned enterprise to be centralized (despite any rhetoric to the contrary) but not necessarily insulated by deliberate legal rules from owner control, as are our corporate managers. That is because the state-owned enterprise does not have a large number of owners for whom the costs of communication and coordination are often prohibitive. In sum, the organizational law of state-owned enterprise would be very different from our corporate law in many major respects.

A more interesting pattern of law would exist in a society that allowed private ownership of capital goods and had significant amounts of advanced technology but a very lopsided distribution of wealth. Perhaps this is the situation in some petroleum exporting countries. In such a society there would be less need than in ours for limited liability and free transferability of shares, because enterprises would rarely have to raise capital from numerous scattered investors (from domestic ones, at least). On the other hand, endowment of entities with legal personality and rules allowing centralized management would still be useful, even for a large enterprise owned by a mod- 
erately small number of investors. Accordingly, in such a society the business corporation might not predominate. Instead, we might find a number of joint ventures or partnerships, and if the corporate form were copied blindly from other countries, we might find many closely held corporations whose corporate characteristics are not fully developed.

In the United States, secondary cost-reduction activities began once the corporate form was strongly established. A general trend can be identified in this secondary phase. The subject of corporate law (including securities regulation) has developed in the direction of cumulative doctrinal complexity, and most of it has been along a small number of clearly identifiable lines. These lines of development may be summarized as follows: the explication by case law and special rules of the fiduciary duty of loyalty, which serves as a check on the abuse of centralized managerial power; the development of exceptions to the principle of limited liability, as in veil-piercing and equitablesubordination cases, also to check abuse of managerial power; the creation of rules, such as the securities laws' disclosure and antifraud rules, designed to generate more and better information useful in countering insiders' abuses, which are made possible by the frequent transfer of shares; and the continued development of the contours of legal personality, as in the charitable-contribution and social-responsibility cases, which concern the proper definition of corporate purpose. These lines of development are extensions of the basic postulates of the corporate system, an elaboration made necessary by controversies arising in new fact situations brought about by new institutional form. These developments, which are amenable to understanding by traditional doctrinal analysis accompanied by only limited reference to exogenous events and nonlegal concepts, occur more frequently than do primary cost-reducing legal inventions.

The precise mechanisms by which these developments are initiated and reinforced are difficult to specify. An important clue is that there is a real bargaining game going on, not just various parties' unilateral selections of legal options that are advantageous in market transactions. Managers and shareholders have disparate powers and interests, yet both groups have some influence with courts, legislatures, and regulatory agencies such as the SEC. The fact that all states offer corporate chartering on their own terms helps ensure that this struggle will not be resolved definitively in favor of either group. ${ }^{14}$ Conse-

14. The phenomenon of competition in corporate charters has been recognized and debated. William Cary sees the process as simply eroding shareholder protections, Cary, 


\section{Legal Evolution}

quently, each group is constantly pushing to modify the legal landscape in a direction favorable to its interests. Sometimes both groups benefit from a change, but sometimes improvement for one group comes at the expense of the other; at the very least, the distribution of benefits is a bone of contention. In such a situation, in which incompletely defined and perhaps conflicting basic postulates are established, and parties with opposing interests face high stakes and have access to lawmakers, cumulative doctrinal complexity is the likely result. ${ }^{15}$

\section{Laws Affecting Capitalists}

In a recent law-review comment, ${ }^{16} \mathrm{I}$ argued that the history of capitalist enterprise has seen four successive stages of extremely rapid growth of major institutions: large entrepreneurially founded corporations, the modern publicly held corporations, financial intermediaries (or institutional investors), and collective savings vehicles such as pension plans and group insurance plans. In the shift from the first to the second stage, the entrepreneurial function was differentiated into ownership and control, and the latter function was taken over by the newly formed profession of business managers. In the shift from the second to the third stage, the ownership function was split into capital supplying and investment management, and the latter was assumed by the new profession of portfolio managers. In the shift from the third to the fourth stage, which is currently under way, the capital-supplying function is itself being divided into beneficial enjoyment and the decision to save, and the latter is being carried out by group representatives and professional savings planners.

On the basis of this account of changes in the capitalist system, one may venture a reasonably clear, lawlike generalization: the capitalmobilizing function continually develops in the direction of increasing specialization and professionalization of its decisionmaking aspects, on the one hand, and increasing scope for citizen participation

Federalism and Corporate Law: Reflections Upon Delaware, 83 YALE L.J. 663, 670-84 (1974), but Ralph Winter has offered a rebuttal to Cary's arguments, Winter, State Law, Shareholder Protection, and The Theory of the Corporation, 6 J. LEGAL STUD. 251, 254.62 (1977). Winter himself does not show affirmatively that the process produces optimal results, and he properly concedes the need for federal preemption of state antitakeover provisions. Id. at 287-89.

15. There may also be a tendency for specific cost-reducing rules to evolve that benefit some parties without hurting others, but not many different, specific lines of development will be subsumable under this tendency.

16. Clark, The Four Stages of Capitalism: Reflections on Investment Management Treatises, 94 Harv. L. REv. 561 (1981). 
in the income from real capital investment, on the other. In my comment, I speculated on the mechanisms of generation, selection, and development of the new roles. It is clear, for instance, that the emergence of the four stages of capitalism is linked to great increases in the sizes of the relevant economic units and transactions.

The major point of this analysis is that the growth of the characteristic roles in each of the stages gives rise to the imposition of a distinctive system of regulatory control. In the last three stages, the legal regulations all attempt to protect the purported beneficiaries of the newly dominant institutional arrangements and of their professional decisionmakers. The successive regulatory strategies include corporate-law rules of fair play, the securities laws, the soundness regulation of financial intermediaries, and the federal pension-reform law. For good and specifiable reasons, these strategies have very different principal objectives, yet their appearance suggests a lawlike generalization about primary cost-reducing legal activity: whenever commercial developments result in role specialization and in a rapid increase in the number of decisionmakers that claim professional status and discretionary powers, the legal system responds by creating a distinctive body of law to protect those intended to be the beneficiaries or "customers" of the professionals. Though this proposition is unavoidably vague, it is hardly meaningless, and one can look for evidence to confirm, disconfirm, or modify it. Moreover, one can call on significant bodies of existing work, such as the large sociological literature on the "professions," to infuse its key terms with operational meaning.

Of course, each new field of law that is created in response to the growth of a particular kind of professional power tends to take on a life of its own and to exhibit its own logic of growth. Full investigation of these fields awaits future scholarship. I would propose, however, that these and other bodies of fiduciary-like law-law relating to control of professional discretion that is supposed to be exercised for another's benefit-are oriented to the reduction of avoidable and unproductive uncertainty. For example, the rule forbidding directors and officers to usurp corporate opportunities, which is a variation on the hoary rule forbidding trustees to take "secret profits," makes sense when seen as a way of preventing managers from covertly and unilaterally fixing their own reward for managerial services, and thus raising investor uncertainty and the cost of capital. As this example suggests, fights over fiduciary principles may have both allocative and distributive consequences. 


\section{Corporate Debtor-Creditor Law}

The law of fraudulent conveyances, which has existed for thousands of years, creates a kind of universal minimum-security agreement between debtors and creditors. It embodies a presumption that most rational debtors and creditors would, if the issues were squarely presented to them, expressly contract for the minimal creditor-protection rules it lays down. It thus lowers transaction costs by freeing parties from continually having to negotiate and contract about very basic rules of a common commercial relationship. ${ }^{17}$ Yet, beginning in the late nineteenth century, new bodies of law arose to provide minimal rules for the protection of creditors of corporate debtors: the bankruptcy doctrines of equitable subordination, cases allowing the piercing of the corporate veil, and statutes imposing restraints on dividends and other corporate distributions. ${ }^{18}$ These developments give rise to a puzzle, for analysis has made it clear that the established principles of fraudulent-conveyance law could be applied to the factual situations dealt with by these new rules, and that the policies and principles behind the new rules are identical or very similar to those underlying fraudulent-conveyance law. ${ }^{19}$ Why, then, did the new rules arise when they did?

The general answer is that the rise of large modern corporate enterprises created new opportunities for cost reduction that could be realized only by new specific rules implementing the old creditorprotection principles. For example, the managers of a large corporation with numerous subsidiaries could cause thousands of transactions to occur among the members of a corporate family. In an insolvency proceeding involving this corporate family, the facts about a fair sample of particular transactions, in addition to evidence that top management of the parent corporation had de facto power to direct most of the transactions and an incentive to insist on terms that were biased in certain ways, may justify inferring the existence of a general pattern of transactions that were fraudulent or unfair to creditors of specified members of the corporate family. In situations of this kind, the doctrine of equitable subordination offers a feasible remedy. Traditional fraudulent-conveyance rules, because of their insistence on prov-

17. In this respect, it is like many aspects of corporation law. See R. PosNER, Economic ANALYsis of LAw 292-96 (2d ed. 1977); Brudney \& Clark, $A$ New Look at Corporate Opportunities, 94 HARV. L. REV. 998 (1981).

18. Technically, the first of these three bodies of law can be invoked in bankruptcies of debtors that are not corporations. But its main use is in the corporate context.

19. See Clark, The Duties of the Corporate Debtor to Its Creditors, 90 HARv. L. REv. 505 (1977). 
ing each unfair transaction and measuring the amount of unfairness, do not. Before the rise of large corporate enterprises, equitable-subordination doctrine, which allows courts to look at an entire situation rather than at minutiae when defining a wrong and to substitute a shotgun for a rifle as the remedy, was less needed and less justified. The paradigmatic case of a fraudulent conveyance was simply that of the individual owner of a failing business who conveys title to his business and personal assets to his wife or to a friend just a short time before his creditors take him to court-or even, as in the deservedly famous Tywne's Case, ${ }^{20}$ while the sheriff is riding over to attach his goods. In these small-numbers situations, a sampling procedure is inapposite.

The story of equitable subordination is an important illustration of the second general theme that one can discern in the evolution of legal rules affecting business organizations and financial practices. Major changes in size, such as growth in the number of participants in business organizations, significantly affect the precise content and general characteristics of legal rules relating to these organizations. One can identify many examples of this phenomenon, ${ }^{21}$ and one can attempt, with a fair hope of success, to identify abstract characteristics that are common to rules designed for large organizations.

\section{Corporate Reorganizations}

The history of the law of creditors' remedies against business debtors has at least five distinct phases. Each is characterized by the emergence and widespread use of a legal procedure, or set of legal principles, that significantly improved the efficiency of the debt-enforcement process for the benefit of creditors and, ultimately, of society. This line of legal development is one of primary cost reduction.

Yet, in striking fashion, each of the later four legal inventions (described below) created a need for more numerous or exacting valuation procedures. Consequently, they created new needs and opportunities for cost-reducing legal safeguards against irrationality, inadequate information, fraud, and other abuses in the valuation process. By the mid-twentieth century, this movement had resulted in a hypertrophy of rules, procedures, and litigation relating to questions of valuation. This fact explains, and is evinced by, the notable preoccupation with valuation that is displayed in the reorganization part of the

20. 3 Coke 80b, 76 Eng. Rep. 809 (Star Chamber 1601).

21. I attempt to do so throughout my forthcoming book on corporation law. $R$. Clark, supra note 9 . 
widely used casebook on corporate finance by Professors Brudney and Chirelstein.22

Consider the five phases. In the beginning, of course, most commercial societies developed legal collection remedies for individual creditors, in part to reduce violence and other externality-producing behavior accompanying self-help. The second step, taken in ancient times by some societies, was the creation of collective procedures for the whole group of creditors to collect from a debtor; that is, liquidation procedures such as those created by early insolvency and bankruptcy laws. Closely entwined with liquidation procedures, in motivating concept and sometimes in practice, were rules voiding preferential transfers. Group collection procedures not only offer the possibility of realizing economies of scale in creditors' efforts to realize on the value of a debtor's assets; they also allow the reduction of many costs created by the disorderly scramble of individual creditors to be first to collect, regardless of any adverse impact on other creditors or on the overall value to be realized on the debtor's assets. Thus, one commentator has argued persuasively that rules about voidable preferences serve the function of preventing an adverse outcome in a situation that is structurally like the Prisoner's Dilemma of game theory, and that those rules therefore eliminate some substantial costs of uncoordinated action. ${ }^{28}$ But because the laws naturally make the debtor's insolvency (in one of many possible senses) a major part of the complex of events that lead to application of a collective liquidation procedure or of the rules about preferential transfers, they create a need to determine whether liabilities (however defined) exceed assets (however defined). To answer this question, some method of valuing assets and liabilities must be chosen.

The third phase, which developed much later in history, involved the use of receivers instead of sheriffs. A receivership can best be understood as a deliberately slowed-down liquidation procedure. Receivers are given adequate, flexible periods of time in which to operate the debtor's business while looking for the best buyer or buyers. The more time they have, the better the prices they might get for particular assets of the debtor. Even more important, they might find a person to buy all or most of the business as a going concern and at a price reflecting the true going-concern value, rather than at a dis-

22. V. Brudney \& M. Chiretstein, Cases and Materials on Corporate Finance 123-73 (2d ed. 1979).

23. Note, Preferential Transfers and the Value of the Insolvent Firm, 87 YALE L.J. 1449, 1451.54 (1978). 
tress price caused by forcing a quick sale in an illiquid or otherwise imperfect market for particular kinds of capital goods and businesses. Whenever the going-concern value of an insolvent debtor's business exceeds its piecemeal liquidation value, and the receivership preserves that excess value, there is a net gain for creditors and society. But this efficient procedure creates a new valuation problem, for the receiver or the supervising court must decide whether going-concern value does in fact exceed liquidation value.

The fourth phase of development occurred in the United States when the equity receivership evolved to the point where all or many of the creditors of the insolvent business debtor could themselves act as the buyers of the business-which would be kept as a going concern, if that made sense-using not cash as the means of payment, but their creditor cla:ms, such as notes, bonds, debentures, or the like, usually valued at face value plus accrued interest. ${ }^{24}$ The creditors could, in effect, initiate a transformation of their debt holdings into stock, or into some mixture of new debt and stock, and at the same time exercise their contractual rights of priority among themselves and against the residual claimants (the old shareholders) in a way that was just as definitive as a real liquidation sale to an outside buyer. This procedure made economic sense whenever there were no or few potential outside buyers with accurate and timely information about the true state of affairs and the future prospects of the business, and when the process of searching for and informing outside buyers would itself be very expensive.

On the other hand, the transformed receivership proceeding-transformed because the usual aim was now to effect a smooth rehabilitation of the business rather than a true liquidation or sale-accentuated valuation problems. Not only did it have to be determined whether going-concern value exceeded liquidation value, but some finite value had to be placed on the whole business. Otherwise, there would be no way of telling where, down the contractually created ranks of creditors and preferred shareholders, it was fair to stop issuing shares and other claims in the newly organized entity owning the business. When a liquidation or receivership results in a true sale to outsiders for cash, this problem simply does not exist. After expenses, the liquidator or receiver pays money to the creditors that are

24. My simplified account stresses the net result and ignores intermediate steps and complications. For a good introductory discussion of the formal steps that were typically involved, see H. HENn, LAw of Corporations 828-29 (2d ed. 1970). 
contractually most senior (for example, bond holders) until either no money is left or their contractually specified due amounts are paid in full; then he pays money to creditors in the next tier (for example, debenture holders); and he continues in that fashion until the money runs out. By contrast, when the business is not converted to cash or its equivalent, the valuation problem must be faced in order to accomplish a distribution of new tickets. Moreover, the valuation problem is made more difficult by the conflicts of interest that various groups of claimants have with respect to one another. In addition, some groups, such as managers that are also substantial shareholders, may have superior access to information, procedural powers to delay, and other bargaining advantages that are irrelevant to the concept of the receivership and hence felt to be unfair.

The fifth and final phase in the development of corporate debtorcreditor law involved the formal establishment of a bankruptcy reorganization law that offered a more structured version of the transformed equity receivership. In the United States, this occurred most definitively with the passage of the Chandler Act in $1938 .{ }^{25}$ The ritual of the self-sale was dropped. All corporations in reorganization would presumptively be subjects of a reorganization plan that would primarily involve a reshuffling of the paper claims against the business assets. Furthermore, such restructuring of debt might be accomplished by a two-thirds majority vote within the classes of debtors, so that a good plan might be forced on otherwise obstreperous creditors. These refinements, however, simply increased the need for careful judicial supervision of the valuation process.

It may be wondered why the final two or three phases in the development of creditors' remedies occurred so late in the history of trade and commerce. One explanation might be that lawyers in early times simply failed to think of the legal inventions and their advantages. The hypothesis would be that the timing of legal innovations is basically a random matter, and that it takes time for ingenious persons to happen to be put in contact with situations that admit of improvement, and to see the solutions. An alternative, more idea-oriented explanation is that earlier lawyers were intellectually blinded by the influence of their modes of legal thought. Some general shift in the dominant conceptual frameworks or value systems of leading lawyers

25. Chandler Act, Pub. L. No. 75.696, 52 Stat. 840 (1938) (current version at 11 U.S.C. $\$ \$ 101-1330$ (Supp. III 1979)). Before this Act, Congress had adopted section 77 in 1933 to provide for railroad reorganizations and section 77B in 1934 to cover other corporations. These were replaced by Chapter $\mathbf{X}$ of the Chandler Act. 
was needed before the new procedures could be conceived, taken seriously, and adopted. ${ }^{26}$

Both explanations may well have some validity. But the hypothesis that seems most powerful to me is more economic and institutional: only with the rise of very large business enterprises were there sufficiently frequent and sizable economies of scale in debt-enforcement proceedings to justify the legal innovations in question. Unless the surplus of going-concern value over liquidation value was substantial, as it might be for a large business, or the debtor business was so large and complex that it would have been impossible or quite expensive to find or to create a fair-sized pool of reasonably informed potential outside buyers, the efficiency benefits of a receivership or reorganization proceeding would not exceed the very substantial administrative, negotiating, and legal costs of the proceeding itself. ${ }^{27}$ In principle, this hypothesis can be tested against the historical evidence.

\section{Priority Patterns}

In an article on the evolution of patterns of legal priority among secured creditors, I identified a succession of basic priority principles. $^{28}$ These were labeled the "first-in-time" principle, the "possession" principle, the "paperizing" principle (as implemented, for example, by the Statute of Frauds and by various rules giving special privileges to holders of negotiable instruments), and the "recording" (or "filing") principle. I analyzed these principles as ways of reducing fraud and "unfixity" costs in secured transactions, and therefore as secondary cost-reducing innovations within a legal field (secured transactions law) that was itself a product of opportunities for a certain kind of advantageous economic specialization. One of my main points was that technological innovations, such as improvements in transportation, communication, and information-handling technology, have changed the relative balance of advantages between the third and fourth principles, and that this fact should have (and now is having) an impact on the relative status of different priority rules.

26. See R. Gordon, Approaches to the Study of Legal Thought and Legal Practice in Late 19th Century America (April 1980) (unpublished paper delivered at a Harvard Law School Seminar on Basic Legal Research).

27. These costs are high in the more advanced proceedings because of the greater need to consider valuation questions.

28. Clark, Abstract Rights versus Paper Rights under Article 9 of the Uniform Commiercial Code, 84 YaLE L.J. 445, 473-79 (1975) ("evolution of the tendency to suppress abstraction"). 


\section{Corporate Tax}

In the most methodologically self-conscious examination of legal evolution that I have undertaken, ${ }^{29}$ I identified seven postulates, or starting points, of the system of federal income taxation of corporations and shareholders in the United States. Each axiom expressed a basic principle of taxation actually adopted by lawmakers at an identifiable time in the past. For example, the seventh and most esoteric principle declared that corporate distributions of property entail no recognition of gain or loss at the corporate level. I also identified and discussed several key principles describing the institutional processes by which the axioms were elaborated, combined, and developed. For example, I suggested that legislatures tend more than courts to prescribe mechanical rules, whereas courts tend to adopt and to use open-ended principles. These principles of development were used in the analysis much as the rules of inference are used in formal deductive systems. In addition, I mentioned some relevant environmental constraints, or background assumptions. For example, the study assumed that corporate and individual tax rates would retain a certain basic relationship, and that the rates would be high enough to make active struggle between taxpayers and the Internal Revenue Service worthwhile. Finally, I interpreted the actual development of a multitude of particular rules and small bodies of law in the corporate tax field as the unfolding of the system of axioms in accordance with the principles of inference. The ordering of many details in this way demonstrated a significant general trend in the history of corporate tax law: an increasingly complex accumulation of administrative regulations, of holdings and principles in the case law, and of statutory emendations along a small number of identifiable lines of development.

The axiomatic presentation of corporate tax law made it possible to forecast, in a methodical and complete way, the effects on the development of legal doctrine of various hypothetical changes in the postulates. Thus, I attempted to show that one particular combination of reforms of corporate tax law held promise as a way of greatly reducing the legal transaction costs of the present system.

Perhaps the main point of interest for students of legal evolution is that this account of the corporate-tax culture did not-and, I think, could not-interpret it as evolving mainly by the progressive introduction of socially efficient, cost-reducing rules. The pattern of development was not in accord with a model of natural selection of

29. Clark, The Morphogenesis of Subchapter C: An Essay in Statutory Evolution and Reform, 87 Yale L.J. 90 (197t). 
Pareto-superior outcomes, as are many primary legal developments; rather, it was more or less in accord with a model of continued struggle among opposing groups over externally fixed resources. The key facts about the corporate-tax world were that both taxpayers and the Internal Revenue Service had continual access to and some influence on the important lawmakers, and that what one group gained, the other lost. That situation was very likely to produce cumulative complexity of legal rules without any offsetting social efficiencies, and with the basic principles both ambiguous and conflicting in their application to many fact situations, complexity became even more likely.

In some respects, the developments in corporate tax law are similar to those in the field of corporation law since the establishment of its postulates. In both cases, basic ideas have, over a long period, been unfolded, or elaborated, and made increasingly complex; in both cases, the process is driven by the continuing struggle of opposing groups (managers against shareholders, taxpayers against the IRS), all of whom have access to courts, regulators, and legislators. One major difference between the two fields of law is that the ratio of zero-sum to nonzero-sum legal resolutions of problems is greater in the tax field than in the corporate field. As a consequence, an analyst working in corporate law is less likely to feel that the choice among alternative legal rules is "arbitrary" or "conceptualistic."

It should be possible, after reflecting on the development of several legal fields, to formulate and to test propositions about the fundamental determinants of certain major formal characteristics of legal developments. Why, for example, are zero-sum resolutions of problems more common in some fields than in others? Why can some fields meaningfully be reduced to a few basic principles, while others cannot? Why in some fields does doctrine grow cumulatively complex, while in others it does not? Why do developments in some legal fields seem endogenous, that is, explainable with few references to changes in nonlegal influences, while those in other fields do not? Some work on these problems has been attempted, ${ }^{30}$ but much remains to be done.

\section{Method}

In this part, I propose a seven-step method for the construction and validation of a full, formal study and explanation of a line of legal evolution.

30. See, e.g., R. Clark, Notes toward a Theory of Legal Evolution (1978) (unpublished manuscript) (on file with Yale Law Journal). 
1. Define the trend. Describe the shift from rule (or rule complex) $A$ to rule $B$ in what you take to be the relevant terminology. ${ }^{31}$ If the line of change has more than two stages, from $A$ to $B$ to ... N, identify and document the relevant common elements in the shift from stage to stage. Examples of this step were given in the accounts of the four stages of capitalism and of the five stages in the evolution of remedies for creditors of businesses. ${ }^{32}$

2. Identify starting points. With respect to many primary cost-reducing legal inventions, this will mean identifying the sources, whether in persons or in institutions, of the generation of new rules or of the variations in old ones. For example, one can try to find out which persons or groups wanted corporate limited liability and why. The process is roughly analogous to the attempt, in the study of biological evolution, to define and to account for genetic variations by a theory of heredity and mutations. To be sure, one could fruitfully stipulate, as did early theorists of biological evolution, that sources of generation and variation exist but are random (that is, unexplained), and proceed to show how, given a random generation of new proposals for legal rules, specified evolutionary mechanisms insure that rules with certain characteristics (efficient rules, or complex and unstable rules, or whatever) are preferentially selected. Nonetheless, identification of sources generally helps to fill out and refine such explanations and to make them more credible.

When the aim is to study the development of secondary cost-reducing legal rules or developments within a clearly defined and wellestablished legal field, the injunction to identify starting points may mean the identification of basic legal rules or principles. The investigations of corporate and corporate-tax law illustrate this process. ${ }^{33}$

3. Identify principles of development. Describe in general terms how the starting points are elaborated, combined, or otherwise developed; that is, describe the "motor" of change. With respect to many primary cost-reducing legal developments, this will mean identifying, and finding evidence of, some evolutionary mechanism that selects the rules in question over rival or alternative rules. For example, the account of the establishment of the basic principles of corporate law assumed that this role was to have been played by the decisions of many rationally self-interested investors and managers. ${ }^{34}$

31. One should look for generalities wherever they are to be found. Accordingly, one should have no preconceived, inflexible ideas about the appropriate units or categories of analysis.

32. See pp. 1247-50 supra.

33. See pp. 1243-47, 1255-56 supra.

34. See pp. 1243-47 supra. 
With respect to fairly endogenous developments within a field of law, to identify developmental principles may mean to describe those individuals that characteristically play important roles in the field, their differing incentives, the institutional setting in which they operate, and the dynamics of the "game" they play. One example appears in the account of corporate tax law..$^{35}$ Somewhat similar ones appear in various attempts to model the behavior of regulatory agencies and their constituents. ${ }^{36}$

4. Identify relevant conditions of development. In connection with primary cost-reducing developments, specify those environmental conditions that bear on how the mechanisms of selection actually operate on the starting points. An example of this technique is the account of environmental conditions favoring the rise of the corporate form of organization. ${ }^{37}$ In other kinds of development, identify relevant data about external events or exogenous variables that bear on how other principles of development operate on the movement away from starting points. An example of this process is the assumption in the corporate-tax account that taxpayers and the IRS have certain basic interests that determine what they have incentives to want to do.

5. Put the explanation together. Tie together the results of following the second, third, and fourth guidelines into an explanation of the trend identified at the first stage. Ideally, this calls for gathering independent evidence of the existence or validity of each element of the explanation and of the existence of the defined trend. This is where the hard work comes in, and where the methodology of the social sciences may be of use.

6. Consider contrary facts and arguments. This entails, in the first instance, that the explanation formulated at the fifth step be capable of being falsified, or at least disconfirmed or "made infirm." Ideally, one should state explicitly what data would disconfirm the explanation, then actively search for that data and for any other data that apparently conflicts with the explanation, and, finally, try to reconcile apparently conflicting data with the explanation. In practice, of course, the person that formulated the particular explanation or theory is not in a good position to look for and to see conflicting data. This testing function, together with the functions of generating objections to the completeness or consistency of the explanation, and of developing and

35. See pp. $1255-56$ supra.

36. See, e.g., Scott, The Dual Banking System: A Model of Competition in Regulation, SO STAN. L. REv. 1 (1977).

37. See pp. 1243.47 supra. 
finding support for allegedly superior alternative explanations, is best performed by other scholars. The practical message of the sixth guideline, therefore, is that the scholar should expose his or her work to criticism by publishing it, and then receive and consider criticism when it occurs.

7. Do thought experiments on the explanatory factors, and when feasible, test the results against the evidence. This step is critical, for unless it is taken, it will be very difficult for the method to produce explanatory patterns and lawlike generalizations that begin to look like true science, or that might be combined with others into something that could responsibly be called a "theory" of legal evolution. The guideline calls for a deliberate conceptual effort to vary one or more of the explanatory elements produced in the second through fourth steps and to analyze the impact on the defined trend. By methodical variations of the explanation's parts, and by conscious effort not to sneak in new explanatory elements as one considers the alternative scenarios, one can clarify and explicate the connections among the ideas in the original explanation, and also predict how specified alternative legal systems would evolve.

These methodical variations and their resulting predictions have two main uses besides clarification of the logic of the original explanation. First, some variations of the explanation may actually have been exemplified by a past or present legal system other than the one covered by the original explanation. If so, the actual trend of legal evolution in the other system can be compared with that generated by the thought experiment. In this way, the explanatory pattern can be confirmed or disconfirmed. I tried to suggest briefly how this process might work in the account of variations in the environmental conditions favorable to the rise of the corporate form of organization. ${ }^{38}$

Second, the thought experiments can help to predict future legal evolution, and to analyze the precise consequences of certain deliberate changes in the elements of the explanation. Thus, by methodically varying all of the basic principles of a field of law, and using the explanatory pattern to analyze the consequences, one can produce a systematic, well-founded consideration and evaluation of possible legal reforms. Such an analysis was offered in connection with the corporate tax system. ${ }^{39}$

Would careful following of this seven-step method lead eventually to something that could properly be called a theory of legal evolu-

38. See id.

39. Clark, supra note 29 , at $135-62$. 
tion? I do not know. The answer depends on whether there is significant order in the real legal world, and on whether legal scholars have the mental power, the drive, and the resources to perceive the order and to formulate a theory about it. My estimate is that application of the method certainly would lead in many fields to the identification and verification of lawlike generalizations about particular kinds of legal change. These generalizations might be at a low level, but they would be much more than mere descriptions or recountings of what has happened. When enough of these generalizations have been produced and confirmed, it may be possible to show that all or many of them can be subsumed under, or perhaps even deduced from, a small set of more general laws of change. ${ }^{40}$ If and when such a stage of legal scholarship is ever reached, one may then venture to say that scholars have developed a yeneral "theory" of legal change, without cheapening the word or improperly suggesting an analogy to the prestigious theories of the natural sciences.

\section{The Use of Other Disciplines}

From the examples sketched in part two, and the guidelines proposed in part three, it should be clear that systematic study of legal evolution will often, though not always, lead the legal scholar to rely heavily on concepts, data, and methods of organizing data that are supplied by the social sciences. The program I have set forth thus raises some familiar questions. Should legal scholars habitually resort to the concepts and data of other disciplines? If they do, should they work in the other discipline, or merely make use of it? Should they restrict themselves to one other discipline, and if so, to which?

In considering the first of these questions, I begin by asking whether the function of academic lawyers should be exclusively determined by their roles as instructors in professional schools, most of whose graduates expect to practice law. The function of the law school as a supply line to the legal profession may suggest that law professors must carry out three kinds of tasks. First, they should learn well, and then teach, bodies of basic legal doctrine-sets of principles and rules that, compared to others, have a long expected life and may be generally applicable throughout the typical law graduate's career. Second, they should learn, and then teach, lawyering skills, such as those involved in analyzing fact situations and applying law to them, ar-

40. I would not say that the two "apparently general patterns of change" I identified above, see pp. 1241-42 supra, should be treated as "laws of change." 
guing cases, and planning transactions. Finally, as scholars, they should function as commentators: they should develop and publish new presentations of law-new compilations, simplifications, explanations, and criticisms-as called for by the constant stream of new developments in the real legal world. One may naturally question whether, within the constraints of time and means, they can do anything else.

In fact, they can and should. With commercial publishers' research services greatly reducing the need for straight legal treatises, ${ }^{41}$ and with distinct clinical programs teaching the skills of lawyering, the professional functions of the law school do not demand that academic lawyers abandon the quest for more academic kinds of understanding that their position within a university entails. Assuming, then, that some legal scholars are to strive for a "broader," "deeper," "more fundamental," "more philosophical," or otherwise more academic understanding of law, can or must they do so without straying from specifically legal data and modes of thought?

They can, but in many areas their doing so will result in work that is narrow, unimportant, uninspiring, and not conducive to an understanding of how things change. Moreover, if purely legal research is done with imagination and apparent ability to illuminate, it will often be based, either overtly or covertly, on general economic, social, or philosophical propositions that derive only from common sense, from anecdotes or case studies, or from individual experience. Though useful, these are inferior and incomplete guides to understanding and criticism. Furthermore, the legal scholar that tries to go only part of the way, borrowing only the bare theoretical concepts and explanatory schemes of another discipline (for example, economics) and routinely applying them to legal phenomena runs the risk of trying to pull rabbits out of an empty hat, and of deluding himself into thinking that he has done so. Good use of another discipline typically requires that the legal scholar reconnoiter all available systematic empirical studies that are relevant to his concerns, and find out how much empirical evidence there is for the particular lawlike generalizations he is importing from that discipline.

The second issue raised about the use of other disciplines is whether legal scholars should work "in" the other social sciences (together with full-fledged social scientists, of course), instead of "raiding" the

41. Practicing lawyers too are performing traditional functions of the legal academic, such as providing a unified overview and introduction to a field. E.g., J. FreUnd, ANATOMY OF A MERGER (1975). No academic lawyer has produced a comparably good exposition of this subject. 
other field for good ideas and data. For instance, should not academic legal scholars make greater use of social science methods to get new and reliable information about processes relevant to their policy concerns? ${ }^{22}$ Why were the program and the initial vigorous efforts of the legal realists not sustained? To the second question, and indirectly therefore to the first, the answer, I think, is that the different systems of incentives, peer pressures, and intellectual trends in the law schools and in the social science departments make it difficult to enlist good academic lawyers in detailed, time-consuming, original, social scientific research on anything like a continuing basis. ${ }^{33}$ There are some happy exceptions, of course. Many economists do empirical research that consists, apart from the tricky task of modeling, of little more than finding already-collected numerical data and subjecting it to statistical tecnniques, such as regression analysis, that many law professors can readily learn. Consequently, a lawyer-and-economist team may find it feasible to test some of their hypotheses against empirical data without having to change or to jeopardize their careers. But the same cannot be said of much original sociological or anthropological research that an academic lawyer might want to have done. Studies like those of Wheeler and his coworkers on the evolution of state supreme courts are, unfortunately, rare. ${ }^{44}$

My neorealist view that academic lawyers typically find it feasible to use the social sciences, though not to work in them in any substantial sense, is not a gloomy or restrictive one. Often, when one is attempting to understand or to assess some area of law, much important, relevant data and some tested empirical generalizations already exist in the literature of one of the social sciences. Often, good material is simply waiting for someone to read it, understand it, and synthesize it, and to make proper use of it in connection with a legally sophisticated analysis of rules and institutions. Unless someone makes a conscious effort to join them, elaborate empirical studies of law-shaped institutions may exist in circles of citation and discussion that are virtually isolated from equally elaborate legal commentaries

42. One noteworthy fact about lawyers' reluctance to collect information themselves is that it was not until a sociology student finally decided to do the job that we obtained data on how the Securities and Exchange Commission actually learns about cases and decides what enforcement action to take. See S. Shapiro, Detecting Illegalities: A Perspective on the Control of Securities Violations (1980) (unpublished Ph.D. dissertation in Yale University Library).

43. The best and most illuminating evidence on this point, I think, is Schlegel's wonderful study of the fate of legal realism at Yale. Schlegel, American Legal Realism and Empirical Social Science: From the Yale Experience, 28 Buffalo L. Rev. 459 (1979).

44. See note 2 supra. 
on legal rules and procedures, and on how practicing lawyers think they work. Certainly this was true five years ago in the field I know best, the law of financial intermediaries, ${ }^{45}$ and it seems obvious that a similar situation now exists in fields such as health-care regulation. In addition, of course, the social sciences' concepts and methods of explanation are often available for use in the analysis of particular problems.

The third issue I raised about the use of disciplines outside the law is whether all legal scholars should devote themselves to the social scientific discipline that is "best" for understanding the law, and ignore the others. Although individual legal scholars may find it infeasible to resort to more than one other discipline, should the community of scholars as a whole also use only economics, for example? The major reason for legal scholars to avoid so restrictive an approach to their scholarship is that the several social sciences complement each other; they are neither good substitutes for one another nor strict competitors. Even though they are in very different states of theoretical development, each can sometimes make contributions to the understanding of law that the others cannot make, or cannot make as well. This is true in three respects.

First, different conceptual schemes are not equally useful for understanding different kinds or aspects of phenomena. The categories and procedures of explanation that make up a conceptual scheme usually were designed to address phenomena at a particular level of generality and to focus on certain kinds of variables to the exclusion of others. Their application to other realms may be intriguing but limited. In most respects, for example, the aggregate operation of the capital markets seems best approached by use of economics. On the other hand, it appears that social psychologists have told us most about the impact of divorce on the mental health of children, and their explanations may usefully be taken into account in formulating family law policy.

To analyze an issue such as whether to legalize gambling, several social science fields may be useful. The economist may tell us that legislation will lead to increased gambling activity because the effec-

45. Prior to two major articles that made extensive use of empirical studies and new developments in economics and finance theory, Clark, The Soundness of Financial Intermediaries, 86 YALE L.J. 1 (1976); Scott \& Mayer, Risk and Regulation in Banking: Some Proposals for Federal Deposit Insurance Reform, 23 StAN. L. REv. 857 (1971), much prominent commentary in the legal literature on banks and insurance companies was rather legalistic or concerned with conventional, uncritical accounts of history and policy. Yet much relevant empirical work had been done by economists. 
tive cost to those who value gambling will be reduced, though the reduction may be small if the previous costs of avoidance, such as traveling to a nearby jurisdiction in which gambling was legal, were not great. The behavioral psychologist may supply an equally important idea: the view, which is supportable by experimental evidence, that much gambling behavior is learned, and that certain schedules of reinforcement for an activity, such as the variable-ratio schedules provided by slot machines, are more likely than others to generate strong, persistent behavior patterns, or more generally, that the establishment of accessible gambling-type contingencies in the human environment will generate and sustain behavior patterns that otherwise would not exist. In more conventional terms, not only the relative costs of satisfying different preferences will be altered; so too will the preferences themselves. The psychoanalyst may offer a third idea, a psychological explanation that is different from the behaviorist's. He might rather explain gambling as reflecting an attempt to satisfy a fixed need or to release ever-present psychic energy, so that if gambling is legally blocked, some closely analogous behavior will surely pop up somewhere else.

Whether or not any of these views is supportable by the evidenceI think the third is not-they all provide explanations of gambling behavior that may be of concern to legal policymakers. Each approaches the problem from a perspective that is radically different from that of the others. All are useful, though none of the three ideas introduced by the social scientists will determine the selection of legal policy. They simply shape the lines of argument and may make them more rational.

A second way in which the social sciences are complementary is that different conceptual schemes may give rise to different illuminating hypotheses. For example, economists have focused on the question whether the law becomes more efficient over time. Durkheim, a sociologist, produced and offered support for the fascinating hypothesis that the increasing division of labor in human societies has led to an increasing ratio of cooperative legal rules to penal and repressive legal rules. ${ }^{46}$ Donald Black, a contemporary sociologist, has offered and given some evidence for a number of striking hypotheses, such as the proposition that the amount of law in a society, measured in any of a variety of ways, increases in proportion to the amount of stratification, measured in any of several ways. ${ }^{47}$ In principle, there is no rea-

46. E. DURkheim, The Division of Labor in Society $147-73$ (2d ed. 1960).

47. D. Black, The Behavios of Law 11-36 (1976). 
son why an economist might not have formulated and developed these ideas, but common sense tells us that it is not the sort of thing likely to be generated within a purely economic framework.

The third way in which the social sciences complement each other is that social scientists of different kinds are likely to generate valuable data of different kinds. In the study of health-care regulation, for example, economists seem to have made the best use of systematically collected data (much of it collected by government agencies and trade associations), but political scientists seem to have been best at generating (that is, collecting and articulating in published form) new, illuminating information-especially information of a sort that is difficult to quantify-and at producing descriptive generalizations about it. 18

\section{Institutional Orientation}

In my judgment, the most productive kind of study of legal evolution at the present time consists of sustained efforts to establish generalizations and theories of the "middle range."49 This means that scholars should focus on particular sequences of legal doctrines and law-shaped institutions rather than on abstract characteristics of law as a whole, or of a very large subset such as "the common law." My aim is not to restrict scholars to tracing a line of cases and rationalizing or criticizing them in the fashion of traditional commentary. Rather, I urge scholars to study major doctrinal developments and discrete fields of law as they have existed over long stretches of time. I also encourage them to be constantly on the lookout for ways to relate their results from many such inquiries to some general explanation of legal change. On the other hand, I am skeptical of attempts to short circuit the process by constructing plausible general theories of legal evolution and then debating them in an exclusively a priori fashion. The time is not ripe for choice among such general theories.

I do not mean that no effort should be made to invent general theories or that provisional general theories may not serve as good heuristic devices in studying evidence about particular legal developments. My main point is that we should all recognize that little can reasonably be expected from present exercises in theory building.

48. See, e.g., T. Marmor, The Politics of Medicare (1973); B. Vladeck, Unloving Care: The Nursinc Home Tragedy (1980).

49. This phrase is taken from the earlier debates among American sociologists, typified by Talcott Parsons on one side and Robert Merton on the other. See J. TURNER, The Structure of Sociological Theory $69-71$ (rev. ed. 1978). 
When built prematurely, general theories, besides being possibly invalid, may be deficient in meaning, utility, testability, and importance, and there may be no good way to choose among them. It would be unfortunate if all legal scholars were diverted by the joys of a-priorism from more sober forms of work. Internalizing the conceptual scheme of another discipline and moving directly into general theory building is something like taking a stiff drink and jumping into a hot tub: there is a certain danger of fatally drifting off.

Let me illustrate my reservations by commenting on one of the best contemporary efforts at general theory building. In the law-and-economics literature, a series of articles by Rubin, ${ }^{50}$ Priest, ${ }^{51}$ and Goodman $^{52}$ offered different but related explanations of why the common law became efficient. (These theorists assumed for their studies that, as Posner has argued, common-law rules serve efficiency to a surprising degree. ${ }^{53}$ ) Subsequent literature has attempted to extend, refine, or modify the basic theme. ${ }^{54}$ The named trio of theorists acknowledged that their work grows out of analytical work on the decision to settle or to go to trial. In a larger sense, their work is also a variation of the Coase Theorem literature, ${ }^{55}$ whose premise is that affected parties can negate an inefficient assignment of liabilities by bargaining and "bribing," provided that the transaction costs of bargaining are sufficiently low. Even if transaction costs are high, the evolutionary theories now add, parties can sometimes negate inefficient rules by going to court, provided, of course, that the costs of doing so are sometimes low enough relative to the expected benefits. The next move, I suppose, is for someone to explore the idea that the affected parties can sometimes negate inefficient rules by going to administrative agencies or legislators, that is, by "relobbying" rather than by "relitigating" or by "bargaining away."

For present purposes, I will focus only on the early evolutionary

50. Rubin, Why is the Common Law Efficient? 6 J. Legsl STUd. 51 (1977).

51. Priest, The Common Law Process and the Selection of Efficient Rules, 6 J. LEGAr STUD. 65 (1977).

52. Goodman, An Economic Theory of the Evolution of the Common Law, 7 J. LrGAL STUd. 393 (1978).

53. See R. POSNer, supra note 17.

54. See Cooter \& Kornhauser, Can Litigation Improve the Law without the Help of Judges? 9 J. Legal STud. 139 (1980); Denzan, Litigation Expenditures as Private Determinants of Judicial Decisions: A Comment, 8 J. LEGAL STUD. 295 (1979); Landes \& Posner, Adjudication as a Private Good, 8 J. Legal Stud. 235 (1979); Michelman, Constitutions, Statutes, and the Theory of Efficient Adjudication, 9 J. LEGal STUd. 431 (1980). In 2 different but related vein, see J. Hirshleifer, Evolutionary Theory in Law and Economics (manuscript prepared for Liberty Fund, Inc., Seminar on Evolutionary Theory in Iaw and Economics, May 16-18, 1980) (on file with Yale Law Journal).

55. E.g., Coase, The Problem of Social Cost, 3 J.L. \& Econ. 1 (1960); Demsetz, When Does the Rule of Liability Matter? I J. LEGAL STUd. 18 (1972). 
theory of George Priest, which is the most provocative one. (I hasten to add that Priest has since left his early theory for more promising ones. ${ }^{50}$ ) His argument in the early work is that inefficient legal rules impose greater costs on the parties subject to them than do efficient ones; that, other things being equal, parties are more likely to litigate than to settle a dispute when the stakes are greater; that, therefore, parties subject to inefficient rules will be more likely than other parties to litigate rather than settle; that relitigation of an inefficient rule may sometimes lead to its being overturned-assuming, at the least, that judges are neither perfectly hostile to efficient rules nor perfectly able to distinguish efficient from inefficient ones; and that the systematically biased input of litigated cases, plus the occasional overturning of inefficient rules, eventually increases the ratio of efficient to inefficient rules among the whole set of legal rules with which courts can deal. Because of this "selective relitigation effect," the evolution of the common law toward efficiency can be explained, if need be, without reference to many apparently relevant facts, such as judges' preferences for efficient rules, or, indeed, without assuming that judges have any thoughts or preferences at all.

Priest was careful to avoid taking any particular position on the actual nature and impact of judges' preferences. He did not purport to show that common-law rules are or ever will be "completely efficient." Rather, Priest argued that

the rate at which efficient outcomes will be achieved will be a function of the nature of the judicial bias for or against efficiency, the frequency of relitigation of inefficient rules (itself determined by the costs of litigation versus settlement, the precedential effect of the rules and the extent of their inefficiency), the rate of change of the social conditions that underlie various disputes, and the adaptability of earlier surviving precedents to the efficient resolution of new disputes. ${ }^{57}$

56. See Priest, Selective Characteristics of Litigation, 9 J. LEGAL STUD. 399 (1980). This article develops a "relative indeterminacy theorem" reminiscent of the randomwalk theory of stock prices: under certain plausible conditions, such as the possibility of mutual gains from settlement, equal access to precedent, and rational expectations, disputes for which parties' estimates of success will conflict-thus prompting them to litigate rather than settle-will be those for which true uncertainty exists in the substantive law. Consequently, although disputing parties will behave rationally and use precedent as well as other information, new decisions will not be seen to be determined by old ones. In fact, Priest claims, no theory of common-law decisionmaking will be able to explain the outcomes of all litigated decisions. Priest's new theory has testable implications-for example, the prediction that plaintiffs and defendants will win about equally often in certain kinds of litigation-and he and some coworkers are now gathering and processing relevant data.

57. Priest, supra note 51, at $\mathbf{8 1}$. 
A selective relitigation effect of some magnitude, Priest thought, is bound to occur under almost any plausible set of values of these variables.

I have reservations of four types about this theory. First, its meaning does not seem specific enough to be very interesting or useful. One has little sense of what kinds of legal rules to expect next in any particular field of law. One is not told where or why subsets of especially efficient or inefficient rules exist, or how efficient, compared to any ideal or actual system, the common law is or will be. Nor is one told what policy conclusions, if any, might follow from the theory. The only pragmatic payoff I can identify is a vague feeling that the world is basically all right; the theory is reassuring or legitimizing rather than disturbing or critical.

I do not mean that highly general, nonspecific theories cannot be good things. But those that are, such as some formulations of Darwin's theory of evolution, are often useful general descriptions of vast numbers of particular descriptions of processes whose existence is fairly well established. Even better, some very general theories, such as Maxwell's theory of electromagnetism, can be used, with the help of auxiliary statements, to deduce empirically well-established lower order generalizations. Priest's theory is in neither of these positions.

Second, Priest offered no evidence for the theory. Being plausible, we must remember, is not the same as being supported by evidence: that the world "makes sense" in our minds only if we believe $\mathrm{X}$ does not imply that $\mathrm{X}$ is true. We are supplied neither with supporting examples of the theory nor with much discussion of the sort of evidence that would falsify, disconfirm, or discredit the theory, or even make it "infirm" or "less likely."

In my unrepentant logical-positivist view, ${ }^{58}$ a theory should be treated as vacuous unless it is formulated so as to be falsifiable or infirmable by evidence yet to be collected. In principle, of course, someone could make a list of all litigable legal rules in existence at some prior time (say, 1880), assess each one to determine whether, in light of the circumstances of the time, it was efficient or not, and construct a ratio of efficient to inefficient rules; he could then repeat the pro-

58. The locus classicus of discussions of falsifiability and the like is $\mathrm{K}$. PORPER, THE Logic of Scientific Discovery (2d ed. 1968). Subsequent philosophers of science have spent much time debating the identity of the preferred concept (falsifiability? disconfirmability?), its precise implications, and its role in actual scientific theorizing. See, e.g., I H. Putnam, Mathematics, Matter and Method: Philosophical Papers 250-69 (1975). Of course, I am not confessing to any other views that are alleged to have been held by logical positivists. 
cedure for a later time (say, 1950), and see whether in fact the magic ratio had increased. Of course, a negative finding could be explained on the ground that because of the press of numerous other forces and developments, the selective-relitigation effect had not had enough time to show itself, or that the system of judicial decisionmaking had been changed by intervening events. Nonetheless, a negative finding would demonstrate that the effect was not as strong as originally expected.

The testing process I have just imagined would be a monumental task. It would be at least as difficult as discerning past judges' preferences from the historical record-a difficulty offered by both Rubin ${ }^{59}$ and Priest ${ }^{80}$ as a drawback of more judge-centered theories of evolution. Moreover, if the task were attempted, the scholars doing it would find, I think, many puzzling and unforeseen situations, patterns, and relationships. If the testing process were approached by samplinglooking, for example, only at legal rules in one or two particular fields in both 1880 and 1950-then the task would be more manageable, and the relevant scholars would be doing something like what my program calls for. It would still be an open question, however, whether the samples represented the development pattern of other fields. Finally, and perhaps most important, even if a variety of modest or ambitious investigations led one to conclude that the ratio of efficient to inefficient rules has increased over time, that fact in itself would give little basis for choosing among the different theories of Rubin, Priest, Goodman, or, for that matter, those who assert simply that, whatever the terminology in which they express themselves, judges do in fact prefer to adopt efficient rules and actively try to do so. What is needed to make Priest's theory a nonvacuously distinct theory is a different empirical test. In principle, such a test could probably be specified, but the task of gathering relevant evidence might be a forbidding one.

My third reservation about Priest's theory concerns the importance of the selective-relitigation effect relative to other influences on legal change. Although the concluding section of Priest's paper refers to a "strong" tendency to efficient outcomes, ${ }^{81}$ the paper nowhere offers either evidence or a good theoretical argument for that assertion. The only practical way to get a fix on this question is by making detailed,

59. Rubin, supra note 50 , at 63 .

60. Priest, supra note 51, at 66 .

61. Id. at 81 . 
institutionally oriented investigations into the development of particular fields of doctrine.

Consider some possibilities. (i) Because the selective-relitigation effect is premised on a gradual, probabilistic process, the rate of evolution toward efficient rules when judges are indifferent to efficiency may be orders of magnitude smaller than the rate of evolution when judges positively prefer efficiency. This possibility has a good parallel in the contrast between the glacially slow process of biological evolution, in which tens of millions of years are small units, and the much more rapid process of cultural evolution. Consequently, the selective-relitigation effect could be a real but trivial factor in the actual evolution of the common law.

(ii) If the selectire-relitigation effect itself operates very slowly, all sorts of more quickly changing influences have a greater chance to affect the ratio of efficient to inefficient rules during any given period. For instance, changed circumstances may make no longer efficient some old, relatively unlitigated and efficient rules; this "natural" generation of inefficient rules may proceed faster than the selective-relitigation effect can undo them. Litigants may go to legislatures to speed up, stop, or reverse the process of generating efficient rules: they may lobby for statutes, for example, to stipulate presumptive limited liability for shareholders, to deny shareholders standing to sue on certain matters, or to extend cumbersome appraisal rights to new procedures. Courts themselves may impose standing barriers that virtually squelch the relitigation of inefficient rules. Even if these rules can themselves be litigated and eventually undone, evolution to efficiency might be delayed for painfully long periods of time.

(iii) A court has some, perhaps great, power to reinterpret a case presented by private parties as actually involving an efficient rule that the court would like to examine and overturn. After all, most of the time, litigants think principally about resolving particular disputes, not about relitigating particular rules. They are quite happy to win by arguing the facts, by arguing how established rules (efficient or inefficient) should be applied to their situation, or by giving the court a potpourri of alternative grounds of decision. Particular disputes are often seen as involving a large number of different legal rules-some efficient, some inefficient; some minor, some major-so opportunities arise for a judge to relitigate some rule other than the one that the poor victim of an inefficient rule had in mind. If the parties cannot accurately predict judicial responses of this sort, the selective-relitigation effect may be greatly slowed. 
(iv) A related point derives from the observation that alternative rules on a single subject may display degrees of inefficiency. This point is especially important for Rubin's variant of evolutionary theory. He assumes that the party that suffers from the costs of an inefficient rule can make a rational calculation of the following sort: if I relitigate this oppressive rule and do not prevail, all I will lose is my litigation costs; if I relitigate and win, I will be free for the indefinite future to enjoy the benefits of the alternative, efficient rule that $I$ have in mind; therefore, given the exact size of my expected litigation costs, the great costs of continuing under the oppressive rule, and so forth, I will (or will not) relitigate this rule. The problem with this calculation is that there may well be a third possibility: I may relitigate an inefficient rule, and the judge may use the occasion to impose an even more inefficient one on me. Once this possibility is taken into account, ${ }^{62}$ it is not at all clear that there cannot be significant periods of time and areas of law in which inefficient rules are systematically relitigated no more, or even less, frequently than efficient ones.

My fourth observation about Priest's early theory concerns its extension beyond the common law. Priest thought that the selectiverelitigation effect is felt not just in traditional common-law adjudication but even when the courts are interpreting statutes or constitutions. One must be grateful for this extension: it offers new possibilities for testing the theory. It also gives me reason to opine that the theory, or its extension, seems disconfirmed by the progression of case-law developments in the corporate tax field.

My tentative appraisal is that it would be false to say that the ratio of efficient to inefficient case-law rules in the corporate tax field has increased since the establishment of the tax about three quarters of a century ago. My tentativeness results in part from uncertainty about whether we are supposed to treat each new statutory or regulatory provision as starting a new line of evolution on which to test Priest's

62. This possibility does not represent an imaginary fear. Consider the case of United States v. Von's Grocery Co., 884 U.S. 270 (1966), and other antitrust decisions of the Warren Court, in which, not once, but repeatedly, litigating antitrust defendants not only failed to have a rule interpreted or changed in a way favorable to them, but had matters made worse for them. Moreover, if we are to believe the analyses of commentators such as Bork, R. Bork, The Antitrust Paradox 217-62 (1978), and Posner, R. Posner, ANTITRUST LAW 96-134 (1976)-ironically perhaps, it is the Chicago-trained commentators that are harshest on the trend of the decisions, although Areeda and Turner are also critical, albeit with a milder tone, 4 P. AREedA \& D. TURner, ANTITRust IAw 29-32, 8489 (1980)-we seem led inevitably to the conclusion that the Court was laying down rules that were progressively more inefficient. 
theory. If so, the selective-relitigation effect would, because of the vast number of statutory and regulatory changes, probably turn out to be trivial. I am also uncertain about what efficiency should mean in the context. The allocative effects of corporate tax law seem to be determined mostly by its postulates rather than by the way particular problems within the fields have been resolved. In any event, particular problems are often resolved by fighting about the appropriateness of competing analogies, and seem to have random, if any, allocative consequences. If efficient rules are those that reduce legal transaction costs involved in disputes over taxation, it would appear that the rules have become dramatically more inefficient over time. On the other hand, certain judicial developments, such as the business purpose doctrine, might be construed as helping to achieve a kind of tax neutrality that prevents an increase in the allocative inefficiency or "excess burden" that is inevitably created by the corporate tax. Demonstrating the validity of this interpretation, however, would be a difficult task and by itself would not justify an overall assessment of increasing efficiency in this field.

Most of my reservations about Priest's early theory concern its most provocative aspects: it is a very general theory built by speculative reasoning upon a small number of concepts and is deliberately designed to rest on as few empirical propositions as possible. Of course, generality, speculation, reasoning, and parsimony are virtues in a theorist. But avoiding the risk or effort of resorting to empirical propositions in the building of a theory can easily mean that it will have no definite or important empirical implications. Regrettably, perhaps, there is no way one can pull a rabbit out of an empty hat.

\section{Payoffs}

The interdisciplinary study of legal evolution, if pursued well, should produce results similar to those of other near-scientific endeavors that have succeeded: an improved ability to understand, to predict, and to control broad legal changes. The earlier discussion treated the feasibility of achieving such results and the methods, types, and levels of study likely to produce them. It may now be asked whether ISLE serves the ideal function of legal scholarship, whatever that may be, and whether it should displace other kinds of legal scholarship or be regarded as a "higher" form of scholarship.

There is no single ideal or primary function of legal scholarship. Legal academics should make various scholarly efforts, to serve various 
useful functions. Good teaching materials and clear but entirely descriptive expositions of fields of law can have enormous value to students. How-to books and quick summaries of rapidly developing fields of law can be invaluable to practicing lawyers. Reform-oriented case commentaries and law-review articles about current legal problems may occasionally have important and good effects on legal developments. Academic legal scholarship can also provide scholars in other fields with information and ideas useful for developing their own understanding of the world. Whether the consumers of legal scholarship are students, practicing lawyers, judges and lawmakers (or those who help or have access to them), or the academic community at large, there will be situations in which a particular law professor has a comparative advantage in doing a particular task and therefore should feel justified in doing it.

Yet law school professors, most notably when they admit new members into their ranks, do not value all kinds of scholarship equally. In many schools, the more academic kinds of scholarship are more prestigious. Can this practice be justified as reflecting the greater social value of more academic kinds of scholarship? I do not know, but I strongly doubt it. Can the practice be justified in some other way? I think it can be. One clue is that the product produced by scholars is, to a large extent, a public good..$^{63}$ The benefits of the scholarship can be consumed by many people without impairing its value to others, and it is impossible for the creator to exclude all nonpaying persons from reaping the benefits.

The author of a useful student guide will be repaid in royalties. The author of a good how-to-do-it book will be rewarded even more richly. But the practical benefits of broad historical, theoretical, and empirical investigations into the law are likely to be indirect, cumulative, and far off in the future. This makes it almost impossible to identify the benefits, let alone to attribute particular benefits to particular people. The academic scholar is hard pressed to find a significant audience of living persons to pay for his results, and once those results are published, they are accessible to almost anyone that can find a university library. Yet, for all that, the academic's work may play an important role in the longrun process of understanding the legal system. My suggestion, then, is that the prestige accorded to academic scholarship-a prestige that can translate into some rather tangible benefits-represents one form of subsidy of a product that is a public good.

63. See Ackerman, The Marketplace of Ideas, 90 YALE L.J. 1131, 1135-41 (1981). 
From another perspective, prestige amounts to a desirable form of social insurance. It is probably true that a great proportion of honest, diligent, intelligent, and technically successful academic scholarship leads to no practical benefits whatsoever, that the lines of inquiry that do have payoffs have very great ones, and that the scholarship that will have a payoff is hard to identify in advance. Because of this situation, scholarly chances that should be taken according to some social cost-benefit calculus would not be taken by individuals, who are usually more risk averse than society as a whole, if their rewards depend on the creation of demonstrably useful results. Accordingly, scholars are partially insured against personal failure by their eligibility for at least some of the prestige subsidy as long as they make a good try. As a part of this system, work is evaluated and rewarded by peers, not by outsiders with sharply defined particular interests, and the evaluation is concerned not with demonstrable social benefit, but with other alleged scholarly virtues, such as thoroughness, creativity, and breadth. Some of these virtues may be statistically correlated with the production of work that later yields social benefits outside the original academic circle, but even that much is not certain.

I would hate to end by suggesting that present practices are perfectly rational. The fact is that much scholarship is done because it is a good in itself to those who do it: it keeps our minds pleasantly busy and provides a reason for social experiences such as this symposium. Moreover, for reasons that have little or nothing to do with ultimate social utility, fads occur in trends of legal scholarship and in the kinds of academic scholarship that attract the greatest prestige. There is much reason, therefore, for those who toil in the celestial gardens of academe to be suitably humble. 